\title{
Soviet era landscape change and the post-Soviet legacy in Latvia
}

\author{
Simon Bell ${ }^{1,1}$, Olgerts Nikodemus ${ }^{2}, Z_{\text {Zanda Peneze }}^{2}$ and Imants Kruze ${ }^{2}$ \\ ${ }^{1}$ Estonian University of Life Sciences, Chair of Landscape Architecture, Tartu, Estonia \\ ${ }^{2}$ University of Latvia, Faculty of Geography, Riga, Latvia
}

\begin{abstract}
The collectivisation of agriculture and the development and application of land improvement "melioration" programmes and technologies, as well as the construction of kolkhoz centres during the Soviet era in Latvia was extensive and has a legacy on the post-Soviet landscape and agricultural economy. A study of a number of rural municipalities in different landscape types, through the comparison of maps from the early $20^{\text {th }}$ century with those from around 2000 , and one example with maps from the 1960s and 1990s, together with field work, revealed the degree of change that had taken place. In particular, there was a significant increase in forest - despite the kolkhoz system being targeted at increasing agricultural outputs, a reduction in the number of farmsteads - in some places this was a result of land battles in the Second World war - and a concentration of residences in villages and widespread drainage of marshes, wetlands and wetter forest. Village centres with concentrations of blocks of flats, storage sheds and industrial units were developed. After 1991 and the restitution of land to the original owners or their descendants, large numbers of kolkhoz agricultural buildings, old estate buildings and some residential blocks became redundant and abandoned. Some of the farmland was also abandoned. The sampled areas show different amounts of landscape change and all showed large numbers of ruined buildings scattered around the area. The question of what to do with these, many of which are robbed of anything useful, vandalised and possibly causing pollution remains open, even after 25 or more years.
\end{abstract}

\section{Introduction}

During the $20^{\text {th }}$ century Latvia experienced several major transformations in land use. In 1935 , agricultural land covered $57.3 \%$ and forests occupied $26.6 \%$ of the land area. By 2000 , the agricultural area was only $38.5 \%$, at the expense of which forest had almost doubled in area, then occupying $44.4 \%$ of the territory [1, 2]. This period covers several major upheavals, including the Second World War, when Latvia was invaded several times and fought over with damaging consequences for the landscape and population (around a third of the population died, were exiled or fled abroad during the war period and many houses were destroyed in the battles). Thus, the current changes,

\footnotetext{
${ }^{1}$ Corresponding author: simon.bell@emu.ee
} 
visible and ongoing as they are, have to be seen in the context of the much more considerable changes which happened, more in some areas than others, as a result of pre-war activities, wartime depredations and Soviet land use policies, the last of which in particular continues to affect the character and appearance of the landscape.

The Latvian landscape underwent many changes under the Soviet system due to several influences:

- All land was nationalised and amalgamated into units either as kolkhoz or sovkhoz, (short forms for kollektivnoe khoziaistvo - collective farm, supposedly owned by its members - or sovietskoe khoziaistvo, state farm, where workers were employees). All the original landowners (who were not deported to Siberia as kulaks) became either members or workers.

- The original settlement pattern of scattered farmsteads was consolidated as people moved into new centres dominated by blocks of flats (urban lifestyle in a rural setting).

- Large production complexes were established, including storage barns, central heating plants, grain silos, sheds for intensive pig or chicken rearing, dairies and "machine tractor stations".

- Land, especially potentially fertile mires were improved ("ameliorated") by extensive drainage and brought into production, resulting in large-scale open fields that removed original field patterns.

- Land considered marginal and impossible for mechanised agriculture was abandoned to become forest.

- The original farmhouses were in often left empty, some destroyed to make large fields or remained in use as storage or for living; sometimes several families lived in what were originally single-family houses.

- Wetter forests areas were often drained to increase timber productivity.

This activity over several decades resulted from an ideologically motivated centrally planned landscape fulfilled through an administrative process [3].

Research was carried out in seven local government units or pagasts (which, since the research was conducted have been amalgamated together with others into larger local government units called novads) to assess the current landscape in the light of the processes noted above and the changes that took place. The research questions are as follows:

1. What has been the impact of the changes to the landscape of Latvia resulting from the Soviet collectivisation process?

2. How does the aftermath of these changes continue to affect the condition and appearance of the landscape?

\section{Materials and Methods}

A limited number of Latvian pagasts was selected for the study. These are found in each of the historical regions of what is now Latvia (Kurzeme, in the west, Vidzeme in the north and centre, Zemgale, in the south and Latgale in the east), reflecting the main variations in land use, soil quality, landform and landscape character. Six examples were selected in all: Vidzeme (Dzerbene and Vecpiebalga), Zemgale (Vecsaule), Kurzeme (Barta and Priekule) and Latgale (Nautreni). In addition, a seventh area was chosen for which more extensive data were available also from Kurzeme (Gudenieki) 


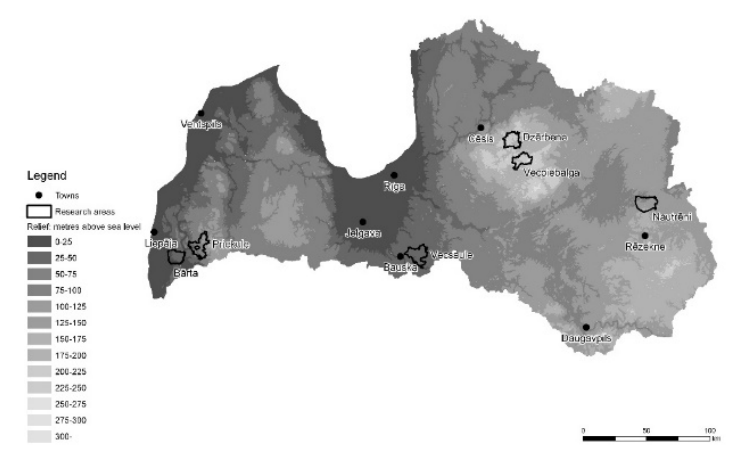

Figure. 1. Location of the study areas.

The map also shows how they are found in different landform types (Source: the authors).

Using the Geographic Information System (GIS) ARCView, two comparative datasets were assembled for six of the study areas: historical maps dating from the early $20^{\text {th }}$ century were digitised to show the main land use types and location of farmsteads before the First World War and aerial orthophotos from the late $20^{\text {th }}$ century were also digitized using the same standards to show the equivalent information for the post-Soviet land use and settlement, updated by some field checking in order to test the extent of land abandonment). For the seventh area Soviet army maps from the 1960s and 1990s were additionally available.

The spatial data recorded in the GIS included forest cover (no additional information on eg. forest type or age was available for the 1900s), fens (bogs and mires) houses/farmsteads, roads, rivers and streams, ditches/drainage channels (showing where land amelioration had occurred) and spots such as kolkhoz centres. All the remaining land was identified as agricultural but could not be defined as pasture or arable owing to absence of data. Two comparative datasets at the same scale were thus created, one for the 1900s and one for the 2000s. The maps for the 2000s also show abandoned land as at 2007. This enables the general land cover and settlement pattern to be observed and analysed separately from the issues of abandonment (Figs. 2-7).

\section{Results}

\section{Land use change in the sample pagasts}

The following maps and bar charts present the changes that took place over the period under discussion. These show different degrees of land use change, in part dependent on a range of factors, such as the original landscape condition. The main reasons for many of the changes can be associated with the political changes and the agricultural planning during collectivisation. All these factors tend to be connected with the larger Soviet political project (see below). One notable aspect is the general increase in forest, the substitution of poor agricultural land by drained mires, the reduction in the number of farmsteads and the concentration of new settlement close to the kolkhoz centres. Note also the amount of land abandonment in some examples. The maps do not of course address how the landscape would be perceived and owing to an absence of height information in the data no feeling for their character as a result of landform variation is possible either. However, the main features can be determined. 


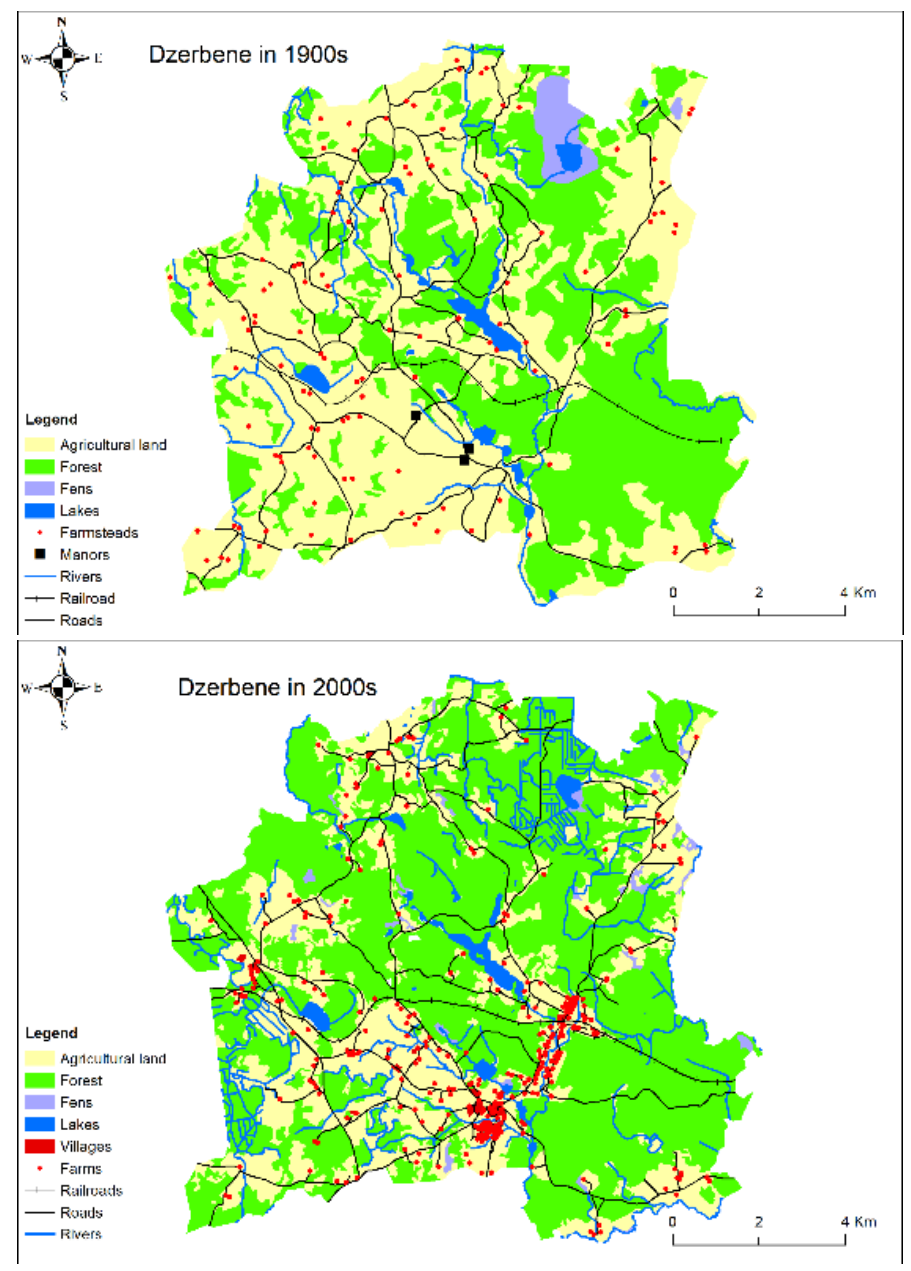

Figs 2a, b. The land use at Dzerbene in the 1900s and 2000s, with abandoned land as at 2007 included. Note the reduction and centralisation of houses as well as the significant increase in forest area (Source: the authors).

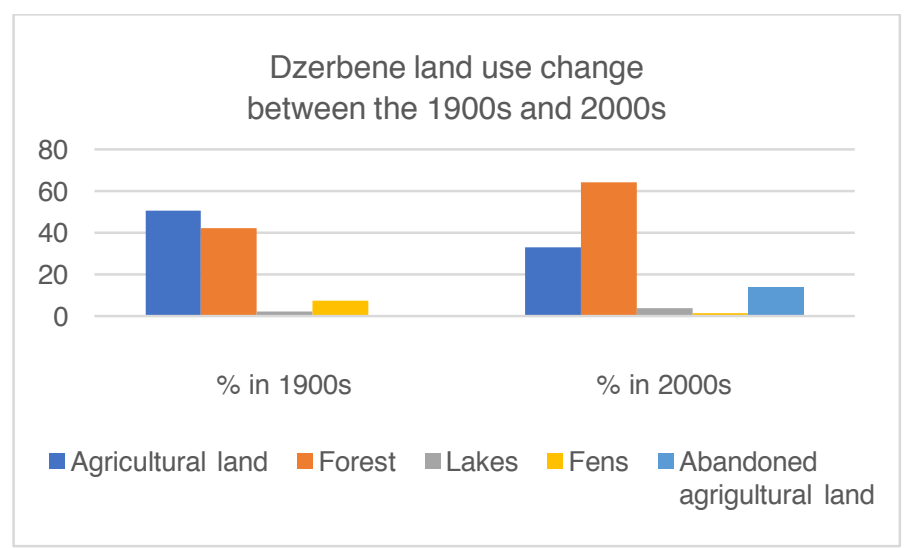

Fig. 3. The land use change at Dzerbene expressed as percentages of the total pagast area. Note that some $10 \%$ of land was abandoned by 2007 (Source: the authors). 

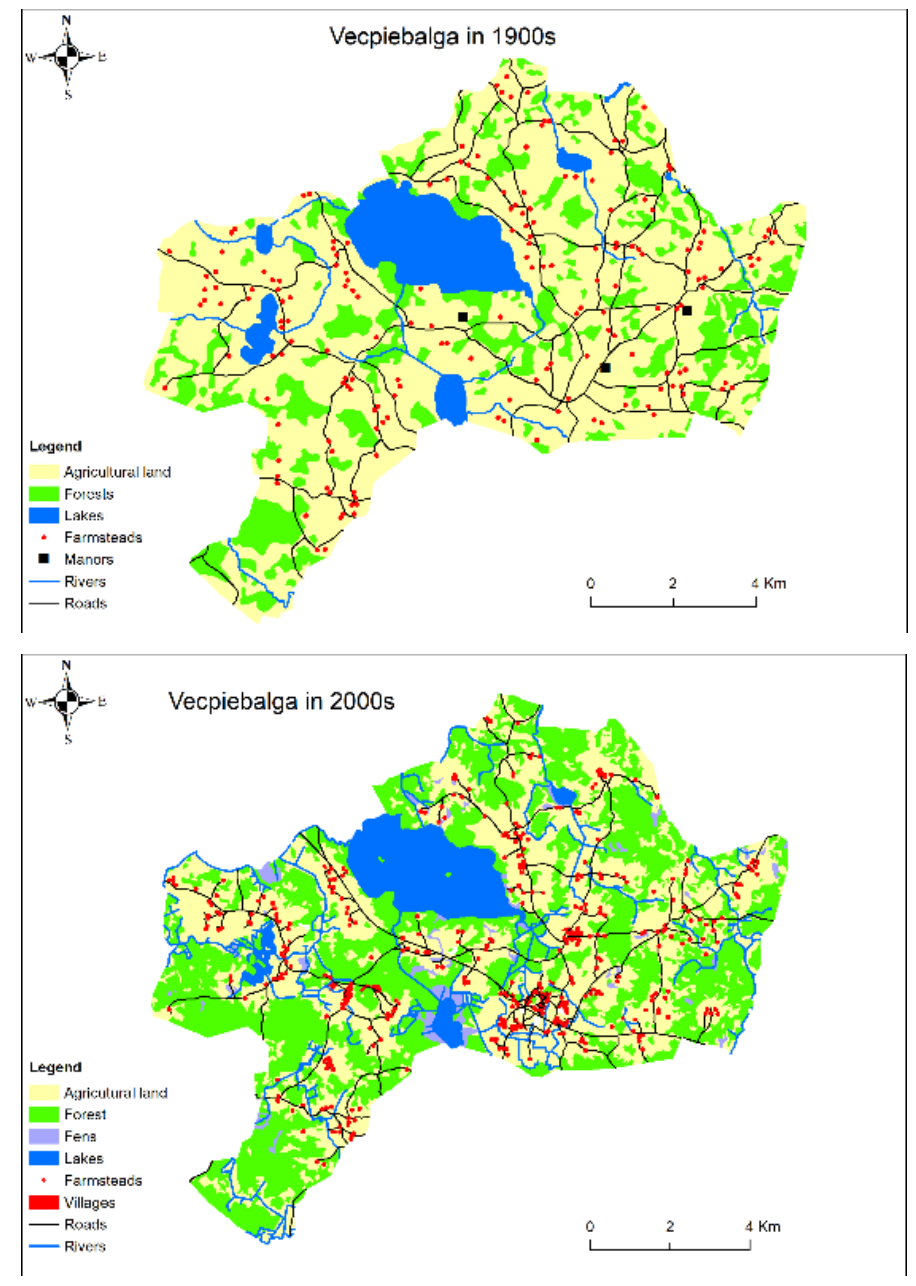

Figs. 4a, b. The land use changes between the 1900s and 2000s at Vecpiebalga, with abandoned land as at 2007. Forest has increased very significantly (Source: the authors).

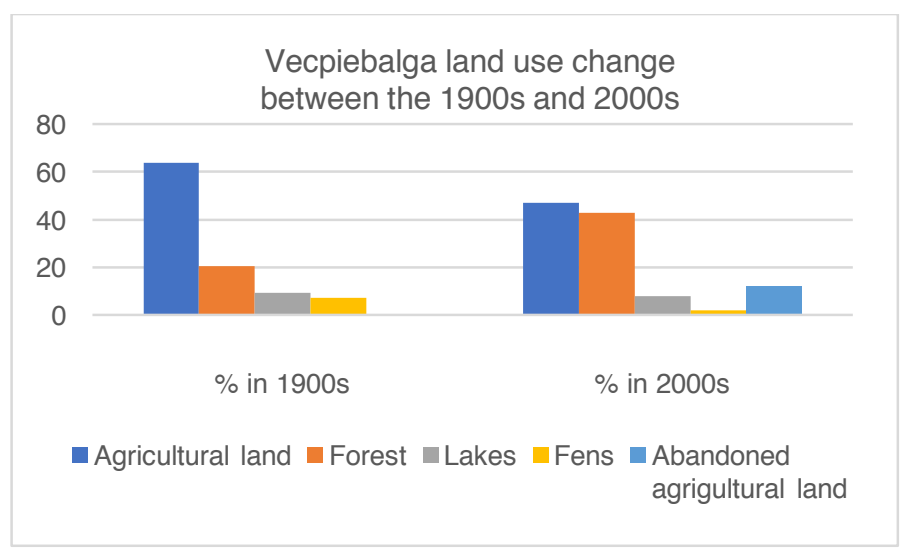

Fig. 5. The land use change at Vecpiebalga expressed as percentages of the total pagast area (Source: the authors). 


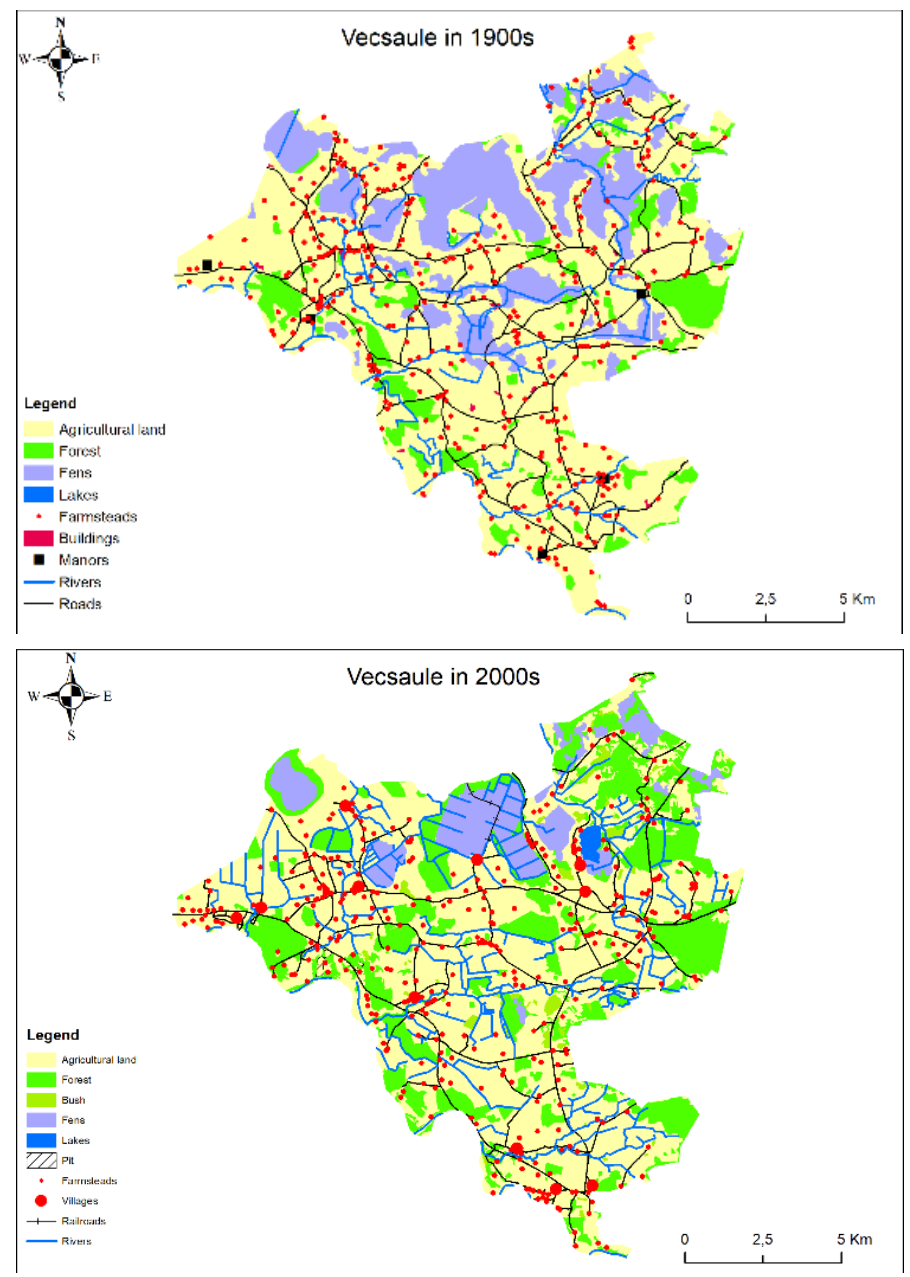

Figs. 6a, b. The land use changes between the 1900s and 2000s at Vecsaule, with abandoned land as at 2007. Note that some farmland became forest while fen was drained for farmland. Some fen was only partially drained (Source: the authors).

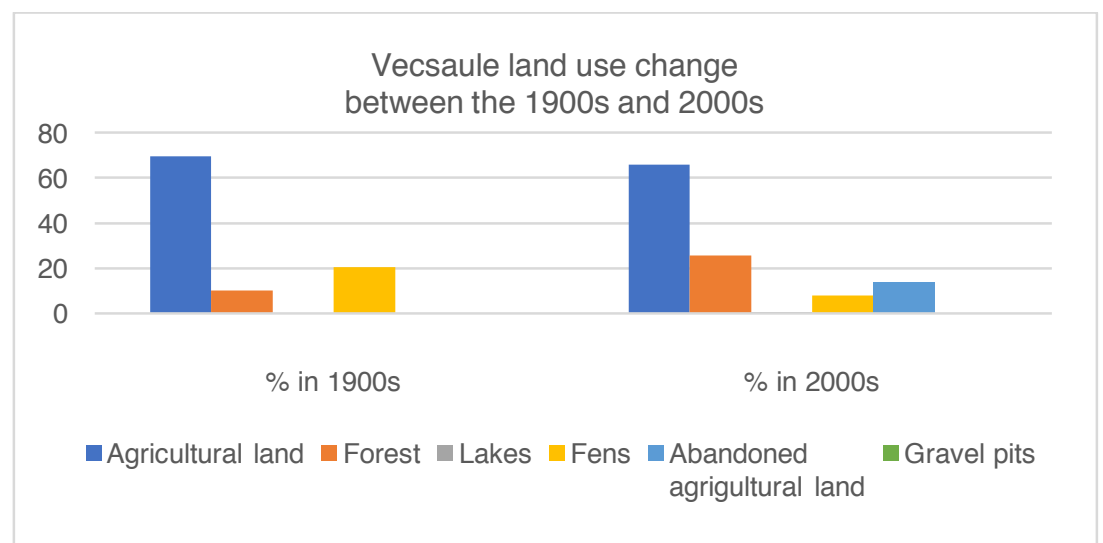

Figure 7: the land use change at Vecsaule expressed as percentages of the total pagast area. The agricultural land has not reduced much in total but it has been displaced and made more productive through amelioration (Source: the authors). 

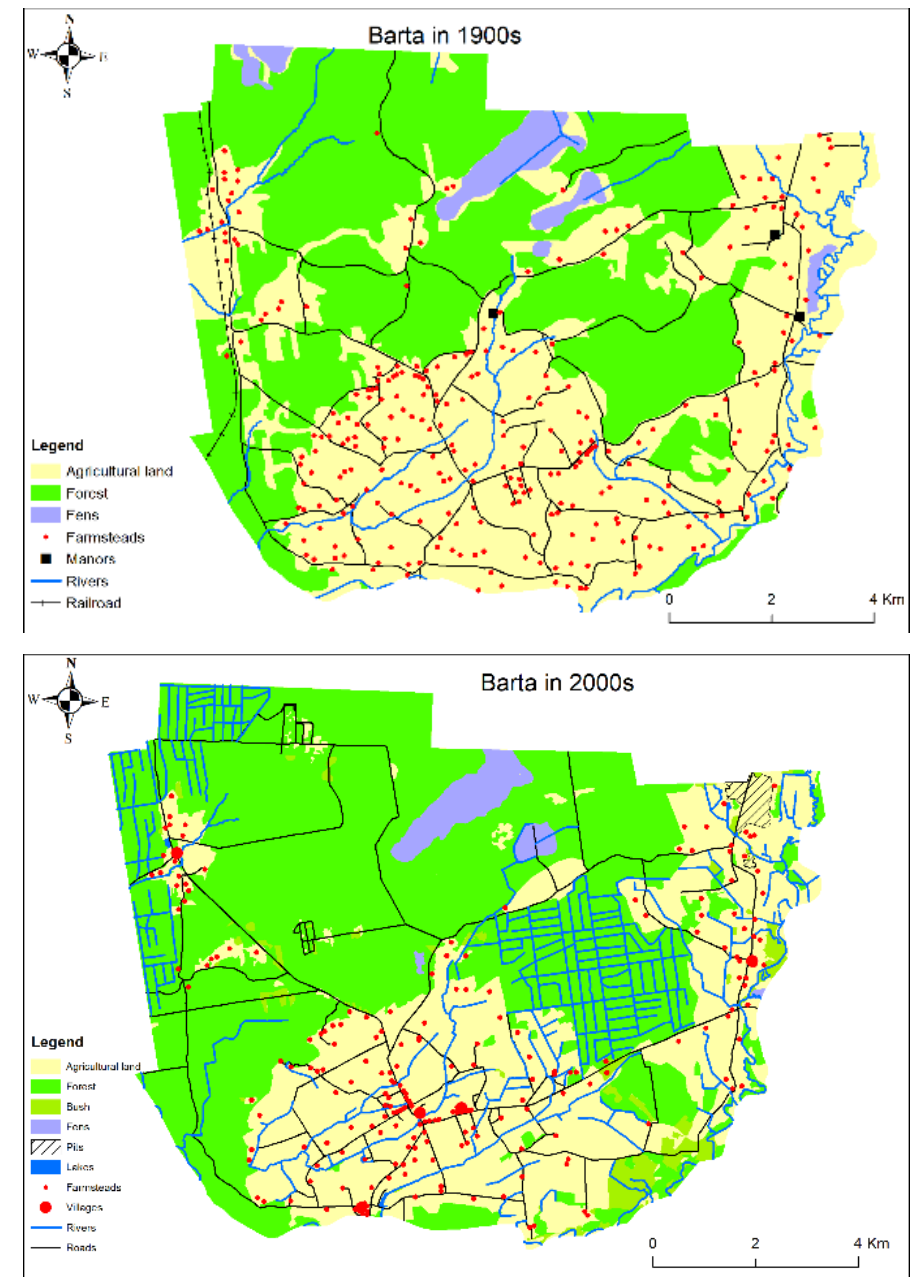

Figures $8 \mathbf{a}$ and $\mathbf{b}$ : the land use change between the 1900s and 2000s at Barta, with abandoned land as at 2007. The forest areas have been consolidated and also drained to increase productivity (Source: the authors).

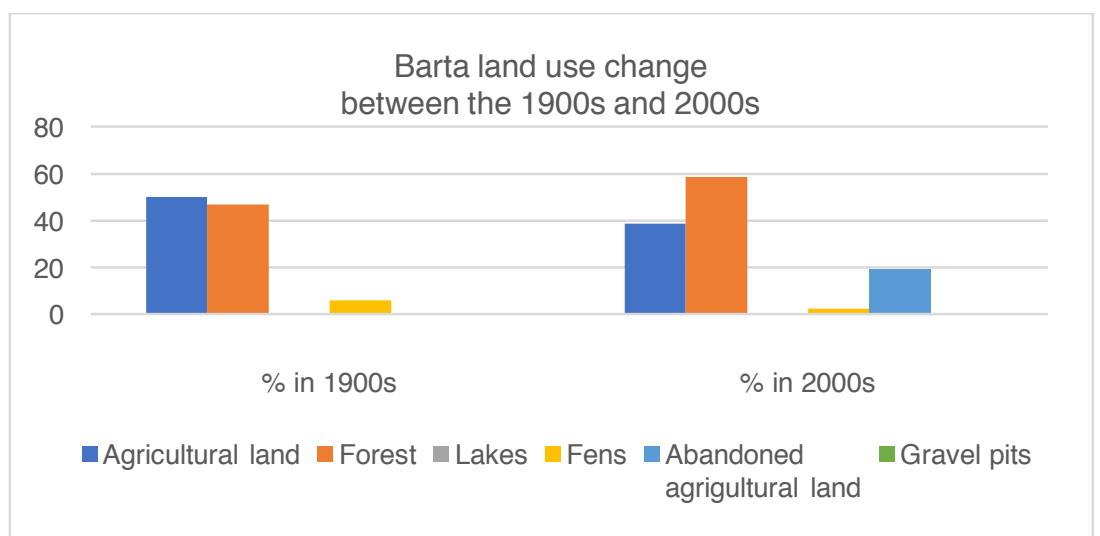

Figure 9: the land use change at Barta expressed as percentages of the total pagast area. Note how much of the farmland was abandoned by 2000 (Source: the authors). 

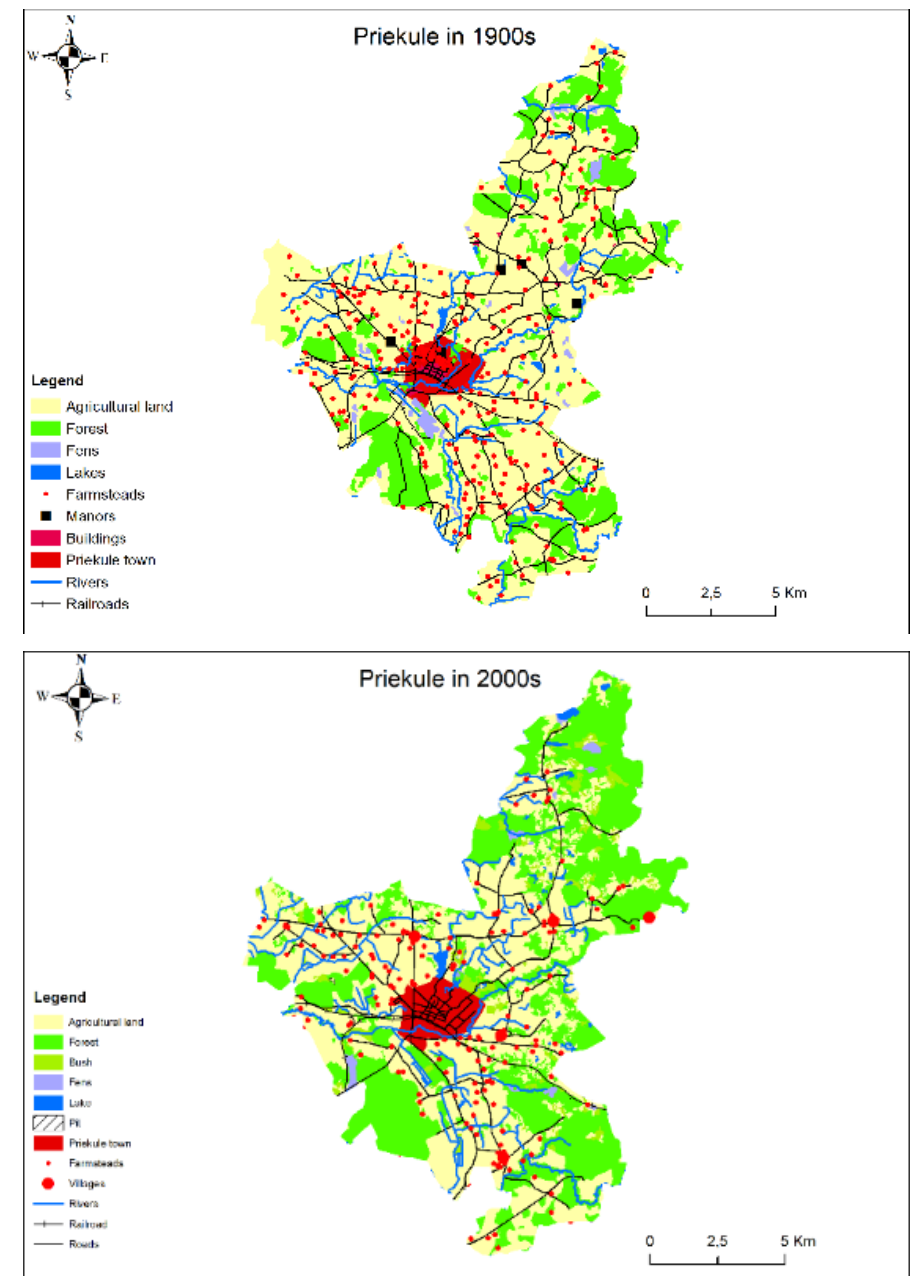

Figures. 10a and b: the land use change between the 1900s and 2000s at Priekule, with abandoned land as at 2007 shown as bush in this case - already considerably overgrown and filling in spaces among the more extensive forest areas (Source: the authors).

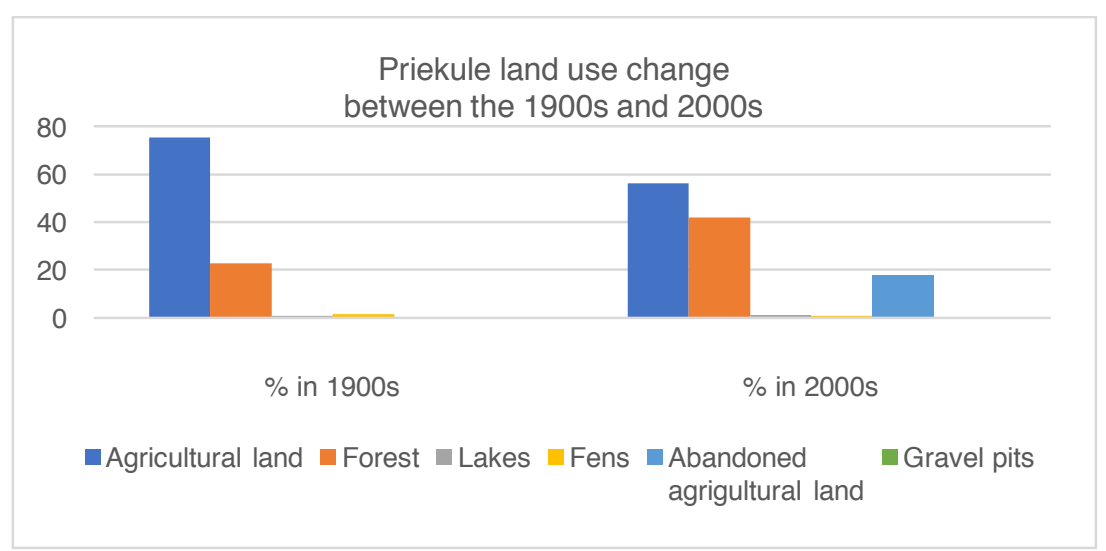

Figure 11: the land use change at Priekule expressed as percentages of the total pagast area (Source: the authors). 

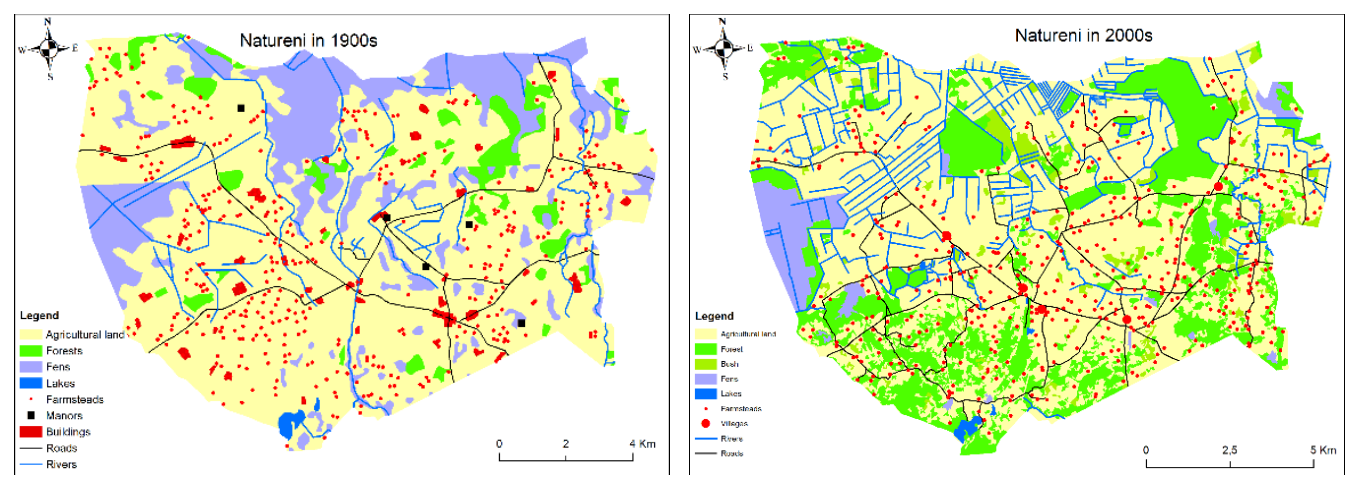

Figs. 12a, b. The land use change between the 1900 s and 2000 s at Nautreni, with abandoned land as at 2007. Forest has expanded mainly in the south where there are sandy hills while the extensive fens in the flatter north have been drained (Source: the authors).

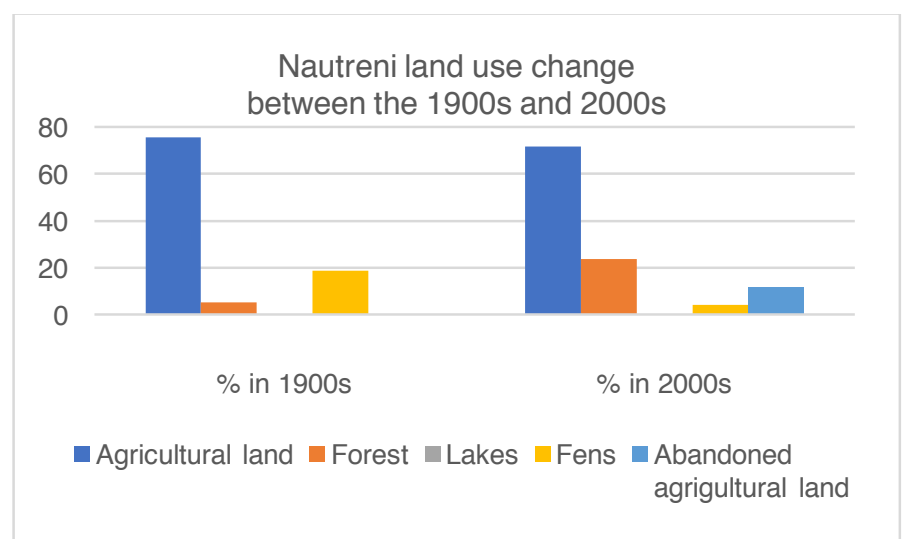

Fig. 13. The land use change at Nautreni expressed as percentages of the total pagast area. Note how there was very little forest in the 1900s but by the 2000s this had expanded to around $20 \%$ and fens had been drained while farmland had not reduced significantly

(Source: the authors).

\section{The story of Gudenieki}

This case study differs from the others because there are more time layers available so that more details of changes can be seen. In addition, a more detailed survey shows the number of farmsteads assessed as derelict in the 1990s just after the collapse of the Soviet Union - these have disappeared from the 2000s map which now shows farms after restitution as being habitable. The first phase of development after the collectivisation was the complete drainage of the large areas of fen and some expansion of forest. The next phase shows how people were moved to the centres and large numbers of farmsteads became derelict. 

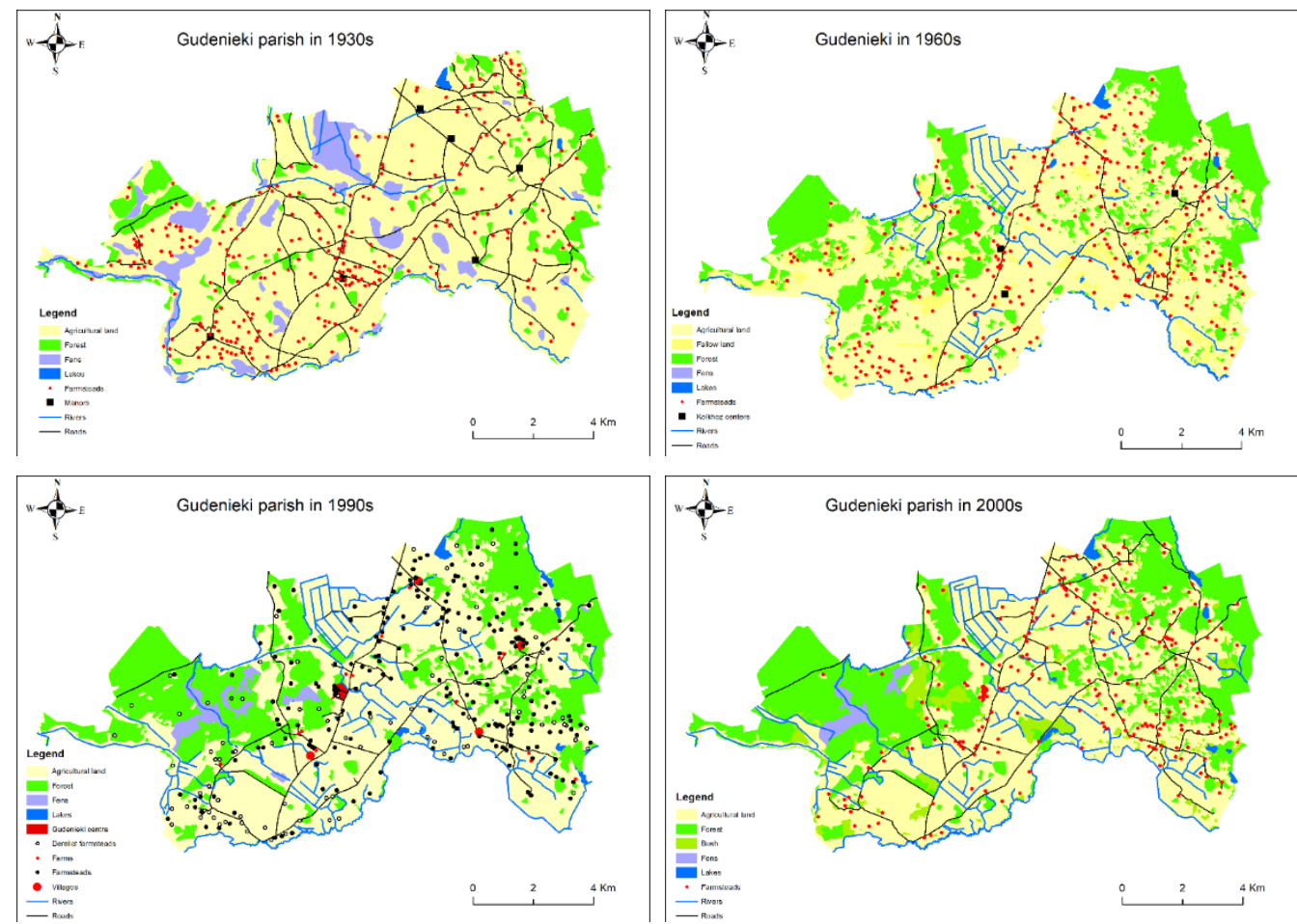

Figs. 14a-d. the land use change between the 1900s, 1960s, 1990s and 2000s at Gudenieki, with abandoned land as at 2000 . Note the gradual increase in forest, with abandoned land in the 1960s showing as forest in the 1990s and bushes in the 200s - when the land had stared to turn to forest after some 10 years of abandonment (Source: the authors)

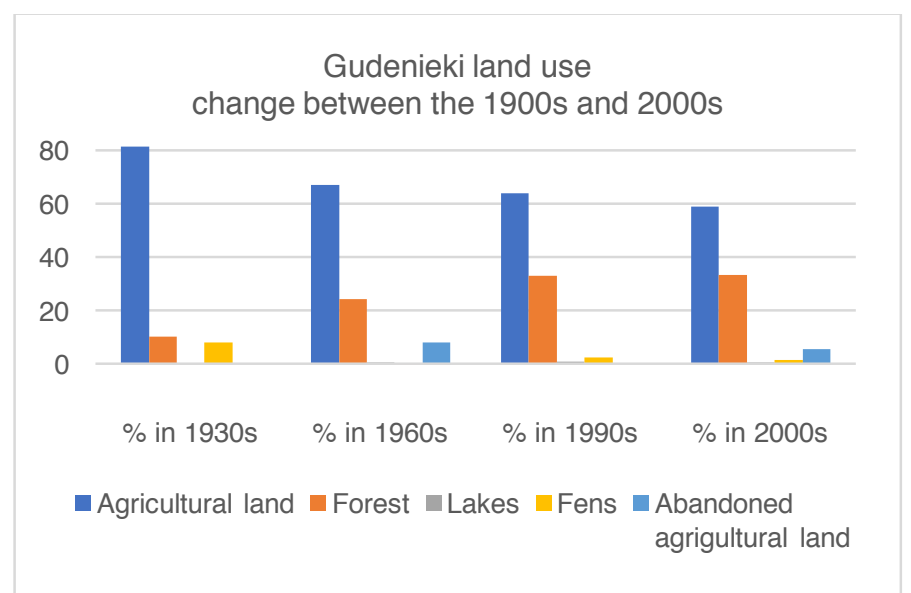

Figure 15: the land use change at Gudenieki expressed as percentages of the total pagast area (Source: the authors).

\section{Discussion}

The results generally suggest that the potential for large-scale amelioration was the main factor affecting the development of the landscape. Thus, the flatter areas with widespread fens, such as Vecsaule and Nautreni, were subject to the most extensive amelioration. The substitution of what was originally agricultural land into forest and fen 
to farmland is one of the most characteristic features. What this means for the landscape can be inferred from the maps, for example rather open landscapes became strongly enclosed by forest and mosaics which would have provided a lot of visual diversity became more monotonous. Forest expanded everywhere but mainly in areas with lower potential for amelioration.

This degree of land use change observed here would never have come about if the land had not been able to be treated as a large-scale single unit: individual farmers would never have had the resources or the ability to carry out such works. Likewise, the rationalisation and establishment of new village centres and new roads would need some kind of central planning. The way each area developed was of course affected by the original character - the land use patterns, core areas of forest and distribution of mires: for example, Dzerbene and Barta were already largely forested, limiting to a degree how much further change was possible. Once the land was returned to the original owners and a pattern of smaller farms was re-established, the large-scale drainage systems, which require regular and comprehensive maintenance, started to break down. Decisions such as whether to maintain cultivation or to abandon the land became more important influencers on the landscape, as seen in the random way that abandonment is shown on the on the maps from the 2000s; small scattered patches occur, often near forested and enclosed areas than large-scale open fields.

On visiting the study areas what also stood out is the large proportion of redundant and ruined buildings which once formed the core of the collective agricultural infrastructure. These were often stripped of useful materials and are left as shells while others were abandoned as they were and in other cases old estate buildings from the 1800 s or 1900 s are also collapsing. Figure 16a-d shows examples of these from one of the sampled pagasts, Dzerbene.
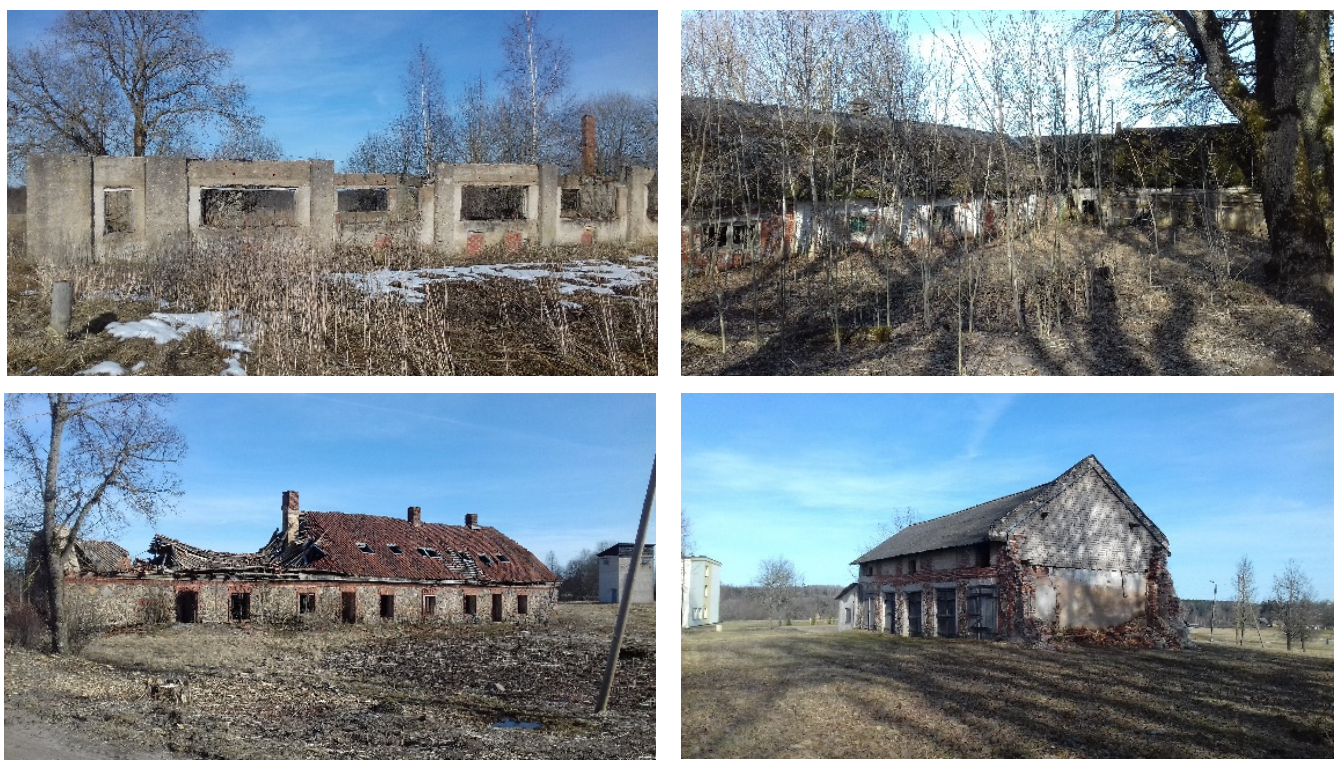

Figs. 16a-d: for examples of ruined buildings, part of the former kolkhoz at Dzerbene (Source: Simon Bell)

Antrop [4] has identified three main phases of landscape development in (western) Europe. Firstly, there is the traditional landscape, visible as pre- $18^{\text {th }}$ century remnants going back to a remote past. Secondly there is the landscape of the $19^{\text {th }}$ century 
agricultural revolution and industrialisation persisting up to the Second World War, with some modern elements in places. Thirdly there is the landscape post-Second World War up to the present day, modern or post-modern and resulting from globalisation and urbanisation. This classification seems to have little room for the Soviet era landscapes - although we see modernism at work in the architecture and modernisation of agricultural practices and infrastructure.

Some aspects of the pre-Soviet Latvian landscape fall in the type of revolutionary age landscape, with the German landowners having affected agricultural practices, at least on the better land $[5,6]$. Land abandonment and the post 1991 changes can be seen to fall into the post-modern landscape types, with the influence of the open markets reappearing after the Soviet Union collapsed and, post 2004, the advent of the Common Agricultural Policy (CAP) of the EU. However, the collectivisation, rationalisation and amelioration processes examined here are not revolutionary, as defined by Antrop, nor post-modern. Thus, for this post-socialist of post-Soviet area we can introduce a new category, that of the 'Ideological Landscape', where a combination of state planning, land nationalisation, strong social control and a division of the population into kulaks and non-kulaks was driven more by ideology than a need to improve agricultural output [7].

If post 1991 the situation falls under has become a type of post-modern landscape, then it has developed over 40 years later than in Western Europe. It is congruent with one of the four trends identified by Klijn and Vos [8]: intensification of and, simultaneously, an increase in the scale of agriculture (such as found in the large-scale arable areas of Vecsaule where the land has been bought by entrepreneurial farmers); urban sprawl (possible closer to the capital, Riga); tourism development based on the quiet, more natural and remoter landscapes, wildlife and charming though not dramatic scenery (offering tourists historical country cottages and saunas set by lakes, in Dzerbene for example); and land abandonment and extensification in remoter areas of Barta and Priekule. Perhaps the intensification and increase in scale of agriculture that took place in the collectivisation period has to some extent gone into reverse with the restitution of land to the previous owners.

There appears to be no longer any significant extensive traditional cultural landscape from before the Soviet era and the dominant character is now the result of the activities of the collectivisation era. The landscape is in many areas much more enclosed, more homogenous, less visually and ecologically diverse and features many ruins and derelict remains of not only Soviet times but also manor estates and other culturally valuable buildings. This analysis suggests a scenario of further extensification and potential abandonment identified by Klijn and Vos above, which seems to be a continuing trend according to the most recent data [9] unless the market of agricultural policies change.

\section{Conclusions}

This paper aimed to address two research questions:

What has been the impact of the changes to the landscape of Latvia resulting from the Soviet collectivisation process? From this study seven sample areas we can observe that the proportions of farmland and forest, fens and settlements, has significantly changed everywhere, though more so in some than others. The landscape has also changed considerably, becoming more enclosed and simplified in structure and with many features lost (old houses) or added (kolkhoz buildings). The landscape is the result of this era, although some traditional features of a small scale remain. 
How does the aftermath of these changes continue to affect the development of the landscape? Following the upheavals of the land restitution period, and a significantly delayed exposure to the forces of post-modernism (globalisation and EU membership) as a result of the Soviet system being isolated from the global economy until 1991 there has been a system-wide shock which led to the dereliction of many of the collective farm assets, still to be seen as monuments to the kolkhoz era, and is also resulting in marginalisation of remoter rural areas.

\section{Acknowledgements}

MODSCAPES is a collaborative research project funded under the HERA - Humanities in the European Research Area 3rd Joint Research Programme dedicated to "Uses of the Past" (20162019). This project has received funding from the European Union's Horizon 2020 research and innovation programme under grant agreement $n^{\circ} 649307$.

\section{Short resume}

Simon Bell $\mathrm{PhD}$ is Chair professor at the Estonian University of Life Sciences and Associate Director of the OPENspace Research Centre at the University of Edinburgh. He has been president of ECLAS, the European Council of Landscape Architecture Schools between 2012 and 2018.

Oḷǵgerts Nikodemus PhD is Professor, Head of Department of Environmental Sciences, Faculty of Geography and Earth Sciences at the University of Latvia. He has made many studies on the development of the rural landscape in Latvia.

Zanda Penēze PhD is Associate professor in the Department of Environmental Sciences, Faculty of Geography and Earth Sciences at the University of Latvia.

Imants Krūze MSc was a researcher in the Department of Environmental Sciences, Faculty of Geography and Earth Sciences at the University of Latvia

\section{References}

1. MINISTRY OF AGRICULTURE, 2001. Agricultural Report (in Latvian), Riga, Ministry of Agriculture.

2. MINISTRY OF ENVIRONMENTAL PROTECTION AND REGIONAL DEVELOPMENT OF LATVIA, 2002. Environmental Indicators in Latvia 2002, Riga, Latvian Environmental Agency. Retrieved from: http://www2.meteo.Iv/produkti/soe2002_eng/ [available on 31 January 2019].

3. MELLUMA, A. 1994. "Metamorphoses of Latvian landscapes during fifty years of Soviet rule", GeoJournal, vol. 33, $\mathrm{n}^{\circ} \quad 1$ : 55-62. DOI: https://doi.org/10.1007/bf00810136

4. ANTROP, M. 2005. "Why landscapes of the past are important for the future", Landscape and Urban Planning, vol. $70, \mathrm{n}^{\circ} \quad 1-2$ : 21-34. DOI: https://doi.org/10.1016/j.landurbplan.2003.10.002

5. ILTNERE, A. (ed.) 2001. Enciklopēdija Latvijas pagasti: Latvijas pagasti, novadi, pilsētu un novadu lauku teritorijas [Encyclopaedia of Latvian Pagasts: Pagasts, Regions, City's and Region's Rural Areas]. Vol. 1, Riga, A/S Preses nams. 
6. ILTNERE, A. (ed.) 2002. Enciklopēdija Latvijas pagasti: Latvijas pagasti, novadi, pilsētu un novadu lauku teritorijas [Encyclopaedia of Latvian Pagasts: Pagasts, Regions, City's and Region's Rural Areas]. Vol. 2, Riga, A/S Preses nams.

7. BELL, S., NIKODEMUS, O., PENËZE, Z. et al. 2009. "Management of cultural landscapes: what does this mean in the Former Soviet Union: A case study from Latvia", Landscape Research, vol. 34, $\mathrm{n}^{\circ}$ 4: 425-455. DOI: https://doi.org/10.1080/01426390903020328

8. KLIJN, J.; VOS, W. 2000. "A new identity for landscape ecology in Europe: a research strategy for next decade", in Idem (eds.), From Landscape Ecology to Landscape Science, (Proceedings of the European congress "Landscape ecology: things to do - proactive thoughts for the $21^{\text {st }}$ century" organised by the Dutch Association for Landscape Ecology (WLO) on the occasion of the $25^{\text {th }}$ anniversary, 6-10 October 1997), Dordrecht, Kluwer Academic Publishers: 149-161.

9. NIKODEMUS, O., BELL, S., PENËZE, Z. AND RASA, I. 2010 The influence of European Union single area payments and less favoured area payments on the Latvian landscape. European Countryside 2:1. 